\title{
MENINGKATKAN HASIL BELAJAR SISWA DENGAN TEKNIK ANALISIS DEKRIPTIF KUALITATIF MATA PELAJARAN BAHASA INDONESIA KELAS VIII SMP NEGERI 4 TEBING TINGGI
}

\author{
Bertha Elyana Gultom \\ Surel : berthaelyanagultom45@gmail.com
}

\begin{abstract}
This study aims to improve student learning outcomes with qualitative descriptive analysis techniques Indonesian subjects. The research subjects were VIII grade students of SMP Negeri 4, Tebing Tinggi city. With the state of the students in the class totaling 30 students where men numbered 16 people and women numbered 14 people. From the results of research on student learning outcomes with the method of Qualitative Descriptive Analysis Technique in Class VIII of SMP Negeri 4 Tebing Tinggi has a positive impact on improving student learning outcomes. Based on the results of the questionnaire analysis the student responses can be concluded that students give a positive response to learning with a Descriptive Analysis Technique approach Qualitative. This is reinforced by interview data which states that students are interested in learning with a Qualitative Descriptive Analysis Technique approach. In addition, it can be seen from the increase in the percentage of students' mastery learning in the pre-cycle (70.17\%), the first cycle $80.42 \%)$, the second cycle (92.50\%).
\end{abstract}

Keywords: Qualitative Descriptive Analysis Techniques, Learning Outcomes, Indonesian Language

\begin{abstract}
ABSTRAK
Penelitian ini bertujuan untuk meningkatkan hasil belajar siswa dengan teknik analisis deksriptif kualitatif mata pelajaran Bahasa Indonesia. Subyek penelitian adalah siswa-siswi kelas VIII SMP Negeri 4 kota Tebing Tinggi. Dengan keadaan siswa dalam kelas berjumlah 30 Siswa dimana Laki-laki berjumlah 16 Orang dan perempuan berjumlah 14 Orang. Dari hasil temuan penelitian tentang hasil belajar siswa dengan metode Teknik Analisis Dekriptif Kualitatif di Kelas VIII SMP Negeri 4 Tebing Tinggi berdampak positif dalam meningkatkan hasil belajar siswa.Berdasarkan hasil analisis angket respon siswa dapat dismpulkan bahwa siswa memberikan respon positif terhadap pembelajaran dengan pendekatan Teknik Analisis Dekriptif Kualitatif. Hal ini diperkuat dengan data hasil wawancara yang menyatakan bahwa siswa tertarik pada pembelajaran dengan pendekatan Teknik Analisis Dekriptif Kualitatif. Selain itu, dapat dilihat dari peningkatan persentase ketuntasan belajar siswa pada pra siklus $(70,17 \%)$, siklus I 80,42 \%), siklus II $(92,50 \%)$.
\end{abstract}

Kata Kunci: Teknik Analisis Dekriptif Kualitatif, Hasil Belajar, Bahasa Indonesia

\section{PENDAHULUAN}

Bahasa Indonesia merupakan salah satu bidang studi yang memiliki tujuan membekali siswa untuk mengembangkan bahasa di samping aspek penalarandan hafalan sehingga pengetahuan dan informasi yang diterima siswa sebatas produk 
bahasa dan sastra. Jadi dalam proses belajar mengajar, seorang guru harus dapat menyampaikan materi dengan baik dan mengajak siswa untuk mendengarkan, menyajikan media yang dapat dilihat, memberi kesempatan untuk menulis, mengajukan pertanyaan dan tanggapan sehingga terjadi dialog kreatif yang menunjukkan proses belajar mengajar yang interaktif. Dalam proses pembelajaran masih sering ditemui kecenderungan meminimalkan keterlibatan siswa. Dominasi guru dalam proses pembelajaran menyebabkan kecenderungan siswa bersifat pasif sehingga mereka lebih banyak menunggu sajian guru daripada mencari tahu dan menemukan sendiri pengetahuan, keterampilan dan sikap yang mereka butuhkan.

Hasil pengamatan guru dengan guru mata pelajaran Bahasa Indonesia Kelas VIII pada bulan September dalam kegiatan belajar mengajar, interaksi guru dan siswa tidak berjalan multi arah, dengan kata lain proses belajar mengajar hanya berjalan dari satu arah, yaitu dari guru saja. Proses pembelajaran di dalam kelas terlihat menjadi aktivitas guru. Hal ini mengakibatkan siswa kurang bersemangat dalam mengikuti proses pembelajaran. Guru praktis menerapkan metode ceramah karena tidak menyita banyak waktu. Selain itu selama ini pula guru kurang. Pada kondisi awal sebelum dilakukannya siklus I, siswa masih kurang antusias dalam belajar. Hal tersebut dapat dilihat dari hasil belajar siswa yaitu dari 30 jumlah siswa Kelas VIII hanya $70 \%$ yang tuntas belajar sedangkan minimal persentase ketuntasan belajar secara klasikal adalah $\leq 85 \%$.

Beberapa asumsi tentang kurangnya antusias dan hasil belajar siswa terhadap pelajaran Bahasa Indonesia sehingga tidak menunjukkan hasil belajar yang diharapkan karena siswa merasa bahasa Indonesia adalah pelajaran yang mudah dan tidak perlu dipelajari. Selain itu guru kurang melaksanakan variasi proses belajar mengajar, pribadi guru yang terlalu menjaga jarak terhadap siswa, keterbatasan sarana selama proses belajar mengajar beranggapan bahwa pelajaran Bahasa Indonesia tidak terlalu penting.

Untuk mengatasi masalah diatas, perlu dilakukannya metode yang dapat meningkatkan hasil belajar siswa terutama pelajaran Bahasa Indonesia. Metode yang digunakan adalah Teknik analisis dekriptif kualitatif . Teknik analisis dekriptif kualitatif merupakan kegiatan yang mengarah pada sikap kritis dan kreatif. Sebab, dalam model pembelajaran ini mengharuskan siswa membuat pertanyaan dari informasi yang diberikan. Padahal, bertanya merupakan pangkal semua kreasi. Orang yang memiliki kemampuan berkreasi dikatakan memiliki sikap kreatif. Selain itu dengan pengajuan soal, siswa diberi kesempatan aktif secara mental, fisik, dan sosial serta memberikan kesempatan kepada 
Bertha Elyana Gultom : Meningkatkan Hasil Belajar ...

siswa untuk menyelidiki dan membuat jawaban.

Tujuan dari penelitian ini adalah untuk mendeskripsikan penggunaan Teknik analisis dekriptif kualitatif terhadap pembelajaran bahasa Indonesiadan mengetahui bagaimana penerapan metode Teknik analisis dekriptif kualitatif dalam meningkatkan hasil siswa Kelas VIII SMP Negeri 4 Tebing Tinggi.

\section{METODE PENELITIAN}

Penelitian tindakan kelas (PTK) yang dilakukan termasuk penelitian eksperimen. Hipotesis tindakan dalam penelitian ini adalah dengan menggunakan metode Teknik analisis dekriptif kualitatif dapat meningkatkan hasil belajar bahasa Indonesia pada siswa Kelas VIII SMP Negeri 4 Tebing Tinggi.

Penelitian ini merupakan jenis penelitian tindakan kelas (PTK). Penelitian ini dilaksanakan secara kolaboratif antara peneliti dengan guru mata pelajaran bahasa Indonesia yang mengampu kelas VIII SMP Negeri 4 Tebing Tinggi.

Tempat penelitian adalah tempat yang digunakan dalam melakukan penelitian untuk memperoleh data yang diinginkan. Penelitian ini bertempat di SMP Negeri 4 kota Tebing Tinggi.

Subyek penelitian adalah siswa-siswi Kelas VIII SMP Negeri 4kota Tebing Tinggi. Dengan keadaan siswa dalam kelas berjumlah 30 Siswa dimana Laki-laki berjumlah 16 Orang dan perempuan berjumlah
14 Orang.

\section{Instrumen Penelitian}

Instrumen ini berfungsi untuk mengambil data melalui pengamatan atas pelaksanaan pembelajaran dengan pendekatan prolem posing. Instrumen dalam penelitian terdiri dari:

a. Tes kemampuan penalaran matematis. Tes kemampuan penalaran matematis berfungsi untuk mengukur peningkatan kemampuan penalaran matematis siswa setelah mengikuti pembelajaran dengan pendekatan Analisis Dekriptif Kualitatif.

b. Lembar observasi keterlaksanaan pembelajaran bahasa Indonesia dengan pendekatan Analisis Dekriptif Kualitatif.

c. Angket respon siswa terhadap pembelajaran dengan pendekatan Analisis Dekriptif Kualitatif. Angket digunakan untuk mengetahui respon siswa terhadap pembelajaran dengan pendekatan Analisis Dekriptif Kualitatif dalam kaitannya dengan aspek-aspek afektif siswa meliputi sikap, minat, konsep diri, nilai dan moral.

Alat pengumpul data dalam penelitian ini adalah tes yang disusun oleh Guru yang fungsinya adalah: (1) Untuk menentukan seberapa baik siswa telah menguasai bahan pelajaran yang telah diberikan dalam waktu tertentu; (2) Untuk 
menentukan apakah suatu tujuan telah tercapai; dan (3) Untuk memperoleh suatu nilai (Arikunto, Suharismi, 2002: 19). Untuk memperkuat data yang dikumpulkan, maka juga digunakan metode observasi (pengamatan) yang dilakukan oleh teman sejawat untuk mengetahui dan merekam aktifitas Guru dan siswa dalam proses belajar mengajar.

\section{Teknik Analisis Data}

Untuk mengetahui kefektifan suatu metode dalam kegiatan pembelajaran perlu diadakan analisis data. Pada penelitian ini menggunakan teknik analisis dekriptif kualitatif, yaitu suatu metode penelitian yang bersifat menggambarkan kenyataan atau fakta sesuai dengan data yang diperoleh dengan tujuan untuk mengetahui pemahaman yang dicapai siswa, juga untuk memperoleh respon siswa terhadap kegiatan pembelajaran serta aktivitas siswa selama proses pembelajaran.

Untuk menganalisi tingkat keberhasilan atau presentase keberhasilan siswa setelah proses belajar mengajar setiap putarannya dilakukan dengan cara memberikan evaluasi berupa soal tes tertulis pada setiap akhir putaran/siklus.

\section{HASIL PENELITIAN DAN PEMBAHASAN}

Pada siklus I, secara garis besar kegiatan belajar mengajar dengan metode pembelajaran Teknik Analisis Dekriptif Kualitatif dilaksanakan belum dengan baik. Hal tersebut dapat dilihat dari Tabel 3 yaitu persentase rata-rata kegaiatan siswa adalah 78,6 \% (kategori cukup). Peran guru masih cukup dominanuntuk memberikan penjelasan dan arahan, karena model tersebut masih dirasakan baru oleh siswa.Siswa masih kurang aktif dalam kegiatan pembelajaran karena belum terbiasa dengan metode pembelajaran Teknik Analisis Dekriptif Kualitatif.

Aktivitas siswa yang harus mendapat perhatian lebih oleh guru adalah membuat soal yang berkaitan dengan penjelasan dan ersama guru membahas penyelesaian dari soal yang dibuat dan dituliskan di papan tulis. Aktivitas tersebut mendapat persentase lebih rendah dibandingkan aspek lain yaitu sebesar $7.0 \%$. Pada saat kegiatan pembelajaram, siswa mulai membaca LKS. Guru juga menginformasikan waktu yang dialokasikan untuk kerja kelompok yaitu 25 menit. Siswa mulai bertanya kepada guru dan peneliti mengenai hal-hal yang tidak mereka pahami. Beberapa siswa bertanya mengenai maksud perintah yang terdapat pada LKS sedangkan siswa lain ada yang bertanya mengenai cara menjawab pertanyaan pada LKS. Guru kemudian mengarahkan siswa untuk menemukan jawaban dari apa yang ditanyakan oleh siswa.

Setelah kerja kelompok berlangsung selama 20 menit, guru memperingatkan siswa bahwa waktu yang dialokasikan hampir habis dan 
Bertha Elyana Gultom : Meningkatkan Hasil Belajar ...

agar siswa mempercepat kerja kelompok.Dalam waktu 5 menit yang tersisa guru memeriksa kondisi setiap kelompok. Siswa bersemangat karena menyadari bahwa kelompok yang telah menyelesaikan kerja kelompok secara lebih awal akan mendapat tambahan nilai. Dapat dijelaskan bahwa dengan menerapkan metode pembelajaran Teknik Analisis Dekriptif Kualitatif pada materi pelajaran diperoleh nilai rata-rata hasil belajar siswa adalah 72,94 dan ketuntasan belajar mencapai $82,35 \%$ atau ada 24 siswa dari 30 siswa sudah tuntas belajar. Hasil tersebut menunjukkan bahwa pada siklus pertama secara klasikal siswa belum tuntas belajar, karena siswa yang memperoleh nilai $\geq 70$ hanya sebesar $82,35 \%$ lebih kecil dari persentase ketuntasan yang dikehendaki yaitu sebesar $85 \%$. tampak aspek-aspek yang diamati pada kegiatan belajar mengajar (siklus II) yang dilaksanakan oleh guru dengan menerapkan metode pembelajarn Teknik Analisis Dekriptif Kualitatif mengalami peningkatan dalam penilaian yang cukup baik dari pengamat dibandingkan dengan siklus I sebelumnya. Penilaian untuk setiap aspek dikategorikan sudah cukup baik.Aspek yang dinilai sangat baik adalah memeriksa benar tidaknya soal dan penyelesaian soal yang dibuat siswa.Secara umum observasi terhadap kegaiatan guru sudah dianggap baik.

Dengan penyempurnaan aspek-aspek diatas dalam penerapan metode pembelajaran Teknik Analisis Dekriptif Kualitatif diharapkan siswa dapat menyimpulkan apa yang telah mereka pelajari dan mengemukakan pendapatnya sehingga mereka akan lebih memahami tentang apa ynag telah mereka lakukan.

Dengan menerapkan metode pembelajaran Teknik Analisis Dekriptif Kualitatif pada materi pelajaran diperoleh nilai rata-rata hasil belajar siswa adalah 75,44 dan ketuntasan belajar mencapai 94,11\% atau ada 28 siswa dari 30 siswa sudah tuntas belajar. Hasil tersebut menunjukkan bahwa pada siklus kedua secara klasikal siswa sudah tuntas belajar, siswa yang memperoleh nilai $\geq 70$ sebesar 94,11 $\%$ lebih besar dari persentase ketuntasan yang dikehendaki yaitu sebesar $85 \%$.

Adanya peningkatan hasil belajar pada siklus II ini dipengaruhi oleh semangat siswa yang meningkat dan sudah terbiasa dengan model pembelajaran Teknik Analisis Dekriptif Kualitatif yang disampaikan oleh guru.Saat melaksanakan diskusi dengan pasangannya, siswa sudah mulai aktif melaksanakan kegiatan diskusi dengan baik dan memecahkan masalah terhadap teks materi yang diberikan oleh guru.Siklus II sudah dianggap baik oleh peneliti sehingga tidak perlu dilanjutkan ke siklus selanjutnya.

\section{Pembahasan \\ Siklus 1}




\begin{abstract}
Berdasarkan pengamatan
peneliti dari tindakan pra siklus, siklus I dan II terjadi peningkatan hasil belajar pada jumlah siswa dan persen ketuntasan belajar secara klasikal. Pembelajaran siklus I menggunakan metode Teknik Analisis Dekriptif Kualitatif menunjukkan adanya pe-ningkatan hasil belajar siswa. Hasil analisis data nilai keterampilan siswa mengenai materi pelaran pada tes siklus I menunjukkan bahwa persentase hasil tes siswa yang belajar tuntas naik sebesar $8,83 \%$ dibandingkan sebelum tindakan.
\end{abstract} Siswa yang belajar tuntas secara klasikal pada siklus I sebanyak 28 siswa atau sebesar 82,35\%. Peningkatan tersebut belum memenuhi target atau indikator keberhasilan yang telah ditetapkan. Selain itu juga masih terdapat beberapa kekurangan dalam pelaksaan pembelajaran. Hasil ulangan siswa pada pelajaran bahasa Indonesia di Kelas VIII masih tergolong kurang, yaitu memperoleh rata-rata 70 , sedangkan Kriteria Kelulusan Minimal (KKM) yang harus dicapai siswa adalah 70. Dari 30 orang siswa yang mengikuti ujian pada pelajaran bahasa Indonesia hanya 28 orang siswa atau $84,25 \%$ yang berhasil mendapatkan nilai di atas nilai 70. Hasil tersebut menunjukkan bahwa pada siklus pertama secara klasikal terjadi peningkatan meskipun belum tuntas belajar, karena siswa yang memperoleh nilai $\geq 70$ hanya sebesar $82,35 \%$ lebih kecil dari persentase ketuntasan yang dikehendaki yaitu sebesar $85 \%$. Hanya saja peningkatan yang terjadi belum optimal karena hasil belajar masih berada dalam kategori kurang dan indeks peningkatan hasil belajar masih berada dalam kategori rendah. Hal ini membuktikan bahwa dengan penerapan metode Teknik Analisis Dekriptif Kualitatif dapat meningkatkan hasil belajar siswa Kelas VIII SMP Negeri 4 Tebing Tinggi. Pada saat kegiatan belajar siswa banyak yang suka bermain sendiri dan susah untuk diatur. Selain itu, menurut mitra kolaborasi guru dalam menyampaikan perintah atau penjelasan masih terkadang mengunakan bahasa yang susah dimengerti dan dipahami oleh siswa sehingga membuat siswa kebingungan. Siswa masih belum mengerti sepenuhnya untuk membuat soal. Penggunaan metode Teknik Analisis Dekriptif Kualitatif adalah salah satu cara yang efektif untuk mengembangkan keterampilan siswa untuk meningkatkan kemampuan dalam menerapkan konsep dengan mengajukan soal. Hal ini sesuai dengan pendapat Thobroni (2012), pengajuan soal merupakan kegiatan yang mengarah pada sikap kritis dan kreatif.Sebab dalam metode pengajuan soal, siswa diminta untuk membuat pertanyaan dari informasi yang diberikan.Pengajuan soal dapat meningkatkan kemampuan belajar siswa karena pengajuan soal merupakan sarana untuk merangsang kemampuan tersebut.Hal ini dapat dilihat dari tiga hal yaitu 
Bertha Elyana Gultom : Meningkatkan Hasil Belajar ...

pengulangan masalah, visualisasi masalah dan penalaran kualitatif siswa.

\section{Siklus II}

Berdasarkan pada hasil pengamatan guru selama melakukan pembelajaran pada siklus I maka dilakukan perbaikan pada siklus II.Tindakan siklus II dilaksanakan, hasil siklus II terlihat terjadi peningkatan jika dibandingkan dengan hasil yang diperoleh pada siklus I. Pada siklus II guru telah mengelola kelas dengan baik sehingga terjadi peningkatan dari siklus sebelumnya. Peningkatan itu dapat terlihat pada proses dan hasil pembelajaran.

Metode pembelajaran Teknik Analisis Dekriptif Kualitatif pada siklus II diperoleh nilai rata-rata ulangan harian siswa adalah 75,44 dan ketuntasan belajar mencapai $94,11 \%$ atau ada 28 siswa dari 30 siswa sudah tuntas belajar. Hasil tersebut menunjukkan bahwa pada siklus kedua secara klasikal sudah tuntas belajar, karena siswa yang memperoleh nilai $\geq 70$ sebesar 94,11 $\%$ sudah memenuhi kriteria dari persentase ketuntasan yang dikehendaki yaitu sebesar $85 \%$.

Pada lembar tugas membuat soal telah disajikan contoh soal sehingga siswa dapat mencermati dan menemukan ide untuk menyusun soal. Guru menjelaskan bahwa siswa dapat membuat soal sebagaimana contoh yang tertera atau membuat soal yang berbeda. Tugas membuat soal pada pertemuan kedua siklus II ini dikerjakan secara individu. Guru menekankan bahwa setiap siswa harus membuat soal yang berbeda dengan kelompok yang lain. Setiap kelompok siswa diberi waktu selama 10 menit untuk menyusun soal dan penyelesaiannya.

Dengan mencermati data hasil tes akhir siklus II, dapat dinyatakan bahwa terjadi peningkatan yang signifikan pada hasil belajar. Hal tersebut didukung berdasarkan jumlah siswa yang mengalami peningkatan hasil belajar. Sebanyak 28 orang siswa tuntas secara klasikal dari 30 siswa setelah dilakukan tes akhir siklus II hasil belajarnya meningkat.Siswa sudah semakin berani mengacungkan tangan terhadap hal yang belum dimengerti dan bersemangat mengkomunikasikan hasil kerja Hal ini menunjukkan bahwa pelaksanaan pembelajaran pada siklus II sudah lebih baik dari siklus I.

Siswa dapat memahami konsep-konsep materi pembelajaran dengan baik karena siswa terlibat aktif pada saat proses kegiatan belajar. Siswa mencari tahu hal-hal penting mengenai materi melalui berpikir, bertukar pikiran dengan teman pasangannya serta mempresentasikan hasil diskusinya.Hasil belajar siswa ini digunakan untuk mengetahui sejauh mana pemahaman siswa terhadap materi pembelajaran yang telah disampaikan.

Melihat hasil tersebut Maka penelitian sepakat untuk tidak meneruskan ke siklus selanjutnya 
karena indikator keberhasilan dalam penelitian ini sudah tercapai.Oleh karena itu, penelitian dihentikan hanya sampai siklus kedua.

\section{SIMPULAN}

Dari hasil temuan penelitian tentang hasil belajar siswa dengan metode Teknik Analisis Dekriptif Kualitatif di Kelas VIII SMP Negeri 4 Tebing Tinggi berdampak positif dalam meningkatkan hasil belajar siswa.Berdasarkan hasil analisis angket respon siswa dapat dismpulkan bahwa siswa memberikan respon positif terhadap pembelajaran dengan pendekatan Teknik Analisis Dekriptif Kualitatif. Hal ini diperkuat dengan data hasil wawancara yang menyatakan bahwa siswa tertarik pada pembelajaran dengan pendekatan Teknik Analisis Dekriptif Kualitatif. Selain itu, dapat dilihat dari peningkatan persentase ketuntasan belajar siswa pada pra siklus $(70,17 \%)$, siklus I 80,42 \%), siklus II $(92,50 \%)$.

\section{DAFTAR RUJUKAN}

Aqib, Zainal, 2013. Model-Model, Media, dan Strategi Pembelajaran Kontekstual (Inovatif). Bandung: Yrama Widya.

Djamarah, S. B. 2002. Rahasia Sukses Belajar. Jakarta: PT. Rineka Cipta.

Kumalasari, K. 2011. Pembelajaran Kontekstual Konsep dan Aplikasi. Bandung: PT Refika Aditama

Kunandar. 2008. Langkah Mudah Penelitian Tindakan Kelas.
Jakarta: PT. Raja Grafindo Persada.

Kurniawati, Dewi. 2009. Meningkatkan Sikap Positif Siswa Terhadap Pembelajaran Matematika Melalui Pendekatan Teknik Analisis Dekriptif Kualitatif pada Siswa Kelas VII SMP Negeri 2 Sewon Bantul Yogyakarta. Yogyakarta: TERAS.

Mufarokah, A. 2009. Strategi Belajar Mengajar. Yogyakarta: TERAS.

Nuraida, R. 2013. Efektivitas Metode Pembelajaran Dengan

Pendekatan Teknik Analisis Dekriptif Kualitatif Menggunakan Lembar Kerja Siswa Terhadap Hasil Belajar Dan Motivasi Akuntansi Siswa Kelas XI Pada Pokok Bahasan Jurnal Umum SMA Negeri 1 Banjarharjo. Semarang: Universitas Negeri Semarang.

Purwanto. 2009. Evaluasi Hasil Belajar. Yogyakarta: Pustaka Belajar.

Sagala, S. 2009. Konsep dan Makna Pembelajaran. Bandung: Alfabeta.

Suryosubroto. 2009. Proses belajar mengajar di sekolah. Jakarta: Rineka Cipta.

Syah, M. 2012. Psikologi Belajar (Ed. Revisi-12). Jakarta: PT. Rajawali Pers.

Syaiful Bahri Djamarah. 2011. Psikologi Belajar. Jakarta: Rineka Cipta.

Thobroni, Muhammad dan Arif. 2012. Belajar dan Pembelajaran. Yogjakarta: Arruzz Media

User, U. 1993. Upaya Optimalisasi Kegiatan Belajar Mengajar. Bandung: Remaja Rosdakarya 